\section{Field Growth and Yield of Tomato Transplants Grown in the Float System Using Low Phosphorus Fertilizer and Height Restricting Cultural Practices}

\author{
James W. Rideout ${ }^{1}$ \\ Mountain Horticultural Crops Research and Extension Center, Department \\ of Soil Science, 455 Research Drive, Fletcher, NC 28732 \\ Additional index words. brushing, clipping, ethephon, tobacco float system, Lycopersicon \\ esculentum
}

\begin{abstract}
The float system is an efficient method of seedling production. This system requires use of cultural practices to prevent excessive stem elongation of tomato (Lycopersicon esculentum Mill.) seedlings. It is not known how these practices affect field growth and subsequent fruit yield and quality. Experiments were conducted in 2001 and 2002 to determine if restricting $P$ supply, delaying fertilizer application, brushing, clipping, and ethephon application affect field performance of transplants. Transplants subjected to these cultural treatments in the float system were compared to transplants conventionally grown in the greenhouse. In 2001, there was little difference in field performance among transplants produced under the range of cultural conditions. Although differences in total fruit numbers or yields were nonsignificant in 2002, conventionally grown transplants produced higher early yields. Seedlings grown with low $P$ fertilizer and receiving delayed fertilization or delayed fertilization plus brushing performed best of all float treatments in 2002. Ethephon application severely reduced early yield while increasing late-season yield. Production of tomato seedlings with low $P$ in float systems is feasible, at least on a small scale for transplanting locally, when delayed fertilization or delayed fertilization plus brushing treatments are used to control seedling height.
\end{abstract}

Production of tomato (Lycopersiconesculentum Mill.) seedlings is labor intensive. Float system technology (Rideout etal., 1994), which is used extensively for production of tobacco seedlings, is less labor-intensive than manual overhead irrigation systems.

Potential advantages of the float system over conventional overhead irrigation include lower production cost, more efficient use of water and nutrients, reduced disease pressure (dry plant foliage), and elimination of nutrient leaching to groundwater below the greenhouse. Briefly, this system involves constructing shallow wooden frames on the floor of the greenhouse. The frames are lined with polyethylene sheeting and filled with nutrient solution formulated with water-soluble, horticultural-grade fertilizers. A solution depth of $10 \mathrm{~cm}$ is typical. Seeds are sown on peat- and

Received for publication 22 Apr. 2003. Accepted for publication 26 Sept. 2003. I appreciate the excellent technical assistance of Dwayne Tate and the staff of the Mountain Horticultural Crops Research Station. Appreciation is extended to Greg Hoyt, Deanna Osmond, Fred Cox, and C. David Raper, Jr. for their review of this manuscript prior to submission to the journal. The helpful suggestions of the anonymous HortScience reviewers are also appreciated. This study was supported in part by a grant from the North Carolina Tomato Growers Association. The use of trade names in this publication is solely to ensure accurate description of experimental conditions. No endorsement or criticism of these products or similar products not mentioned is intended.

${ }^{1}$ Assistant Professor of Soil Fertility, North Carolina State Univ. vermiculite-based soilless media in polystyrene flats, floating on this nutrient solution. All irrigation is by capillary movement of nutrient solution up into the media. The nutrient level of the soilless media is generally low enough that the majority of the nutrients needed for seedling growth are provided by the nutrient solution.

Tomato transplants can be grown successfully in the float system (Rideout and Overstreet, 2003; Wyatt, 1998). Excessive stem elongation, a potential problem both in float and conventional culture, can be controlled by using a fertilizer with a low P content along with cultural practices such as delayed fertilizer application, brushing, clipping, or a single ethephon application (Rideout and Overstreet, 2003). However, it has not been determined what, if any, effect these practices have on posttransplant field growth of tomato plants.

Low Pfertilization in a float system reduces the $\mathrm{P}$ concentration of the transplant tissues (Rideout and Overstreet, 2003). Nutrient solution $\mathrm{P}$ concentrations below $2 \mathrm{mg} \cdot \mathrm{L}^{-1}$ in greenhouse production reduced root growth and early tomato yield in field production (Liptay et al., 1992). Low P fertility in the greenhouse tomato reduced maturity and early yields of tomato in field production (Melton and Dufault, 1991). However, manipulation of $\mathrm{P}$ nutrition, within certain limits, of pepper transplants in the greenhouse does not affect field performance (Bar-Tal et al., 1990; Dufault and Schultheis, 1994; Nicola and Basoccu, 1994). Reduction in seedling tissue $\mathrm{P}$ levels by low $\mathrm{P}$ fertility in the float system does not affect field performance of tobacco (Rideout and Gooden, 1998, 2000). Low N rate is used along with low $\mathrm{P}$ in the float system. Low $\mathrm{N}$ fertilization of tomato transplants has been reported to reduce first harvest yield of fresh market tomato (Vavrina et al., 1998). In a review of 10 published studies, Dufault (1998) concluded that field response of tomato to transplant nutrition is inconsistent.

Also of interest is whether cultural practices imposed with the low $\mathrm{P}$ fertilization affect field growth and yield. It has also been reported that transplant nutrition, hardening, and handling did not affect yield of processing tomato (Hartz et al., 2002). Although brushing did not decrease yield of processing tomato (Garner and Bjorkman, 1999), the authors express concern that yield of earlier-flowering fresh-market cultivars could be reduced by brushing. Long-term brushing did reduce yield of some but not all varieties studied (Johjima et al., 1992).

Clipping and ethephon have been used to control size of field-grown transplants without reducing yield or fruit size (Campbell, 1976). Ethephon application to field-grown transplants increased early yield of large transplants (Liptay et al., 1981), but Pisarczyk and Splittstoesser (1979) report that ethephon concentrations of 1000 or $2000 \mathrm{mg} \cdot \mathrm{L}^{-1}$ did not effect the yield of greenhouse-grown transplants. However, results from a preliminary greenhouse pot study (J.W. Rideout, unpublished data) suggested that pretransplant clipping may delay fruit set. Ethephon treatment of tobacco seedlings in the pretransplant stage of growth has been reported to suppress post-transplant field growth (Kasperbauer and Hamilton, 1978).

While float-grown tomato seedlings produced higher early yields than conventional transplants, overall yields were not affected (Wyatt, 1998). Wyatt (1998) used water soluble 20N-8.8P-16.6K fertilizer, which provided much higher $\mathrm{P}$ rates than $15 \mathrm{~N}-2.2 \mathrm{P}-12.5 \mathrm{~K}$ or $15 \mathrm{~N}-0.87 \mathrm{P}-16.6 \mathrm{~K}$ fertilizers used by Rideout and Overstreet (2003). Given the potential benefits in control of stem height by lower $\mathrm{P}$ fertilization, along with other cultural practices, it seems prudent to test the field performance of these seedlings.

This study was conducted to determine if production of tomato transplants in the float system using the cultural systems proposed by Rideout and Overstreet (2003) has detrimental effects on field performance. Specifically, the objectives of this study were to determine the effects of low Pfertilization and height-restricting cultural practices in the float system on: 1) post-transplant plant growth;2) fruit yield; and 3) fruit size.

\section{Materials and Methods}

Seedling production. Eight batches of tomato seedlings ('Mountain Fresh') were grown in a polyethylene-covered greenhouse using different cultural practices (Table 1) at the Mountain Horticultural Crops Research Station near Fletcher, N.C. Wooden frames were constructed and lined with black polyethylene 
sheeting $(0.15 \mathrm{~mm})$ to form the float tanks. Seedlings were grown in 128-cell (cell size $3.6 \times 3.6 \mathrm{~cm}$ ) polystyrene Todd flats (Speedling, Sun City, Fla.). Flats were filled with a noncommercial soilless 1 peat : 1 vermiculite mixture. Dolomitic lime $\left(5.5 \mathrm{~kg} \cdot \mathrm{m}^{-3}\right)$ was the only nutrient source added to the soilless mix. Flats were seeded with 'Mountain Fresh' tomato. One seed was placed in each cell and covered with $\approx 1 \mathrm{~mm}$ finely ground peat. Flats were floated on the nutrient solutions immediately after seeding. All water and nutrients were supplied via capillary movement upward through the media.

Conventionally irrigated, greenhousegrown transplants served as a control. These were watered as needed, and fertilized weekly with water soluble $20 \mathrm{~N}-8.8 \mathrm{P}-16.6 \mathrm{~K}$ fertilizer solution $\left(300 \mathrm{mg} \cdot \mathrm{L}^{-1} \mathrm{~N}\right)$ starting at a height of $\approx 10 \mathrm{~cm}$. Height-restricting cultural practices were not used on the control transplants. Due to their slower growth, conventional transplants were seeded 1 week earlier than the float-grown transplants. The conventional transplants were grown in the same research greenhouse as the float transplants.

With the exception of the delayed fertilization treatments, water-soluble fertilizer was added to float solution immediately before flats were seeded. The two $\mathrm{P}$ rates used were $1.5 \mathrm{mg} \cdot \mathrm{L}^{-1}$ (from $15 \mathrm{~N}-0.87 \mathrm{P}-16.6 \mathrm{~K}$ ) and $3.6 \mathrm{mg} \cdot \mathrm{L}^{-1}$ (from $15 \mathrm{~N}-2.2 \mathrm{P}-12.5 \mathrm{~K}$ ). In all treatments, the initial nitrogen rate was $25 \mathrm{mg} \cdot \mathrm{L}^{-1}$. Potassium rates varied due to the differing $\mathrm{K}$ content of the two fertilizers and were not adjusted. Previous research has determined that $\mathrm{K}$ rate does not usually affect transplant growth (Dufault, 1998). One additional application of fertilizer at the initial rate was made halfway through the experiment for all float treatments. In the case of the delayed fertilization treatments, flats floated on plain water until fertilizer was added on day 10 after seeding.

Transplant brushing was accomplished by bending the plants five times to $45^{\circ}$ angle with a wooden dowel daily starting on day 10 after seeding. The ethephon ( $300 \mathrm{mg} \cdot \mathrm{L}^{-1}$ solution) treatment was applied as a foliar spray (sufficient spray to uniformly wet foliage) on day 13 after seeding. For the clipping treatment, transplants were clipped once on day 16 after seeding by a raised lawn mower fitted with a high-vacuum blade to remove leaf tissue from the upper leaves without damaging the apical meristem.

Transplants were grown $\approx 3$ weeks from seeding. Shoots of 10 representative seedlings per treatment were harvested immediately prior to transplanting. Stem height was measured from the stem base to the apical meristem (Table 1). A more complete description of the effects of these treatments on seedling growth and nutrient composition was reported by Rideout and Overstreet (2003).

Field culture. Field experiments were conducted at the North Carolina State Univ. Mountain Horticultural Crops Research Station near Fletcher, N.C. The soil series was a Codorus loam (fine-loamy, mixed, mesic Fluvaquentic Dystrochrepts) in 2001 and a

Table 1. Greenhouse treatment description and seedling height of tomato transplants measured immediately prior to transplanting in 2001 and 2002. Conventionally grown seedlings were irrigated by hand as needed. Fertilizer rate for all float treatments was at the rate of $50 \mathrm{mg} \cdot \mathrm{L}^{-1} \mathrm{~N}$, which was applied in two applications of $25 \mathrm{mg} \cdot \mathrm{L}^{-1} \mathrm{~N}$ each. Fertilizer rate for the conventional treatment was $300 \mathrm{mg} \cdot \mathrm{L}^{-1} \mathrm{~N}$ applied in place of an irrigation once a week.

\begin{tabular}{|c|c|c|c|c|c|c|}
\hline \multirow[b]{2}{*}{ Treatment } & \multirow{2}{*}{$\begin{array}{l}\text { Float } \\
\text { system }\end{array}$} & \multirow[b]{2}{*}{ Fertilizer } & \multirow{2}{*}{$\begin{array}{c}\text { Initial fertilizer } \\
\text { application }\end{array}$} & \multirow{2}{*}{$\begin{array}{c}\text { Cultural } \\
\text { height control }\end{array}$} & \multicolumn{2}{|c|}{ Initial height } \\
\hline & & & & & 2001 & 2002 \\
\hline & & & & & \multicolumn{2}{|c|}{----- cm ----- } \\
\hline Conventional & no & $20 \mathrm{~N}-8.7 \mathrm{P}-16.6 \mathrm{~K}$ & $10 \mathrm{~cm}$ tall & none & 12.8 & 17.9 \\
\hline High P & yes & $15 \mathrm{~N}-2.2 \mathrm{P}-12.5 \mathrm{~K}$ & seeding & none & 24.2 & 28.1 \\
\hline Low $P$ & yes & $15 \mathrm{~N}-0.87 \mathrm{P}-16.6 \mathrm{~K}$ & seeding & none & 23.6 & 26.5 \\
\hline Clipping & yes & $15 \mathrm{~N}-0.87 \mathrm{P}-16.6 \mathrm{~K}$ & seeding & clipping & 18.4 & 17.5 \\
\hline Ethephon & yes & $15 \mathrm{~N}-0.87 \mathrm{P}-16.6 \mathrm{~K}$ & seeding & ethephon & 19.0 & 17.3 \\
\hline Brushing & yes & $15 \mathrm{~N}-0.87 \mathrm{P}-16.6 \mathrm{~K}$ & seeding & brushing & 18.0 & 19.3 \\
\hline Delayed fertilization & yes & $15 \mathrm{~N}-0.87 \mathrm{P}-16.6 \mathrm{~K}$ & delayed $10 \mathrm{~d}$ & none & 18.8 & 24.7 \\
\hline \multirow{2}{*}{$\begin{array}{l}\text { Delayed fertilization/ } \\
\text { brushing }\end{array}$} & & & & & & \\
\hline & yes & $15 \mathrm{~N}-0.87 \mathrm{P}-16.6 \mathrm{~K}$ & delayed $10 \mathrm{~d}$ & brushing & 16.6 & 17.8 \\
\hline
\end{tabular}

Elsinboro loam (fine-loamy, mixed, mesic, Typic Hapludults) in 2002. Standard production practices for growing staked fresh-market tomatoes with black polyethylene mulch were used (Konsler and Gardner, 1990).

Experimental design was a randomized complete block with four replications. Each plot consisted of a single row of 11 plants. Plant spacing was $46 \mathrm{~cm}$ within the row and $1.5 \mathrm{~m}$ between rows. Seedlings were transplanted to the field on 25 June 2001 and 30 May 2002.

Plant height was measured 28 and $40 \mathrm{~d}$ after transplanting in both years. Seven plants from the middle of each plot were measured. Six consecutive plants from the middle of the row were chosen for harvest. Fruit were harvested weekly starting on 6 Sept. 2001 and 8 Aug. 2002. A fruit was considered ready for harvest if any pink or red color appeared on the blossom end of the fruit. Harvested fruit was separated into US combination (US \#1 and US \#2), US \#3, and cull grades (U.S. Dept. Agr., 1997). The US combination grade consisted of extra-large (>72 mm), large (64-72 mm), and medium $(58-63 \mathrm{~mm})$ fruit. Fruit in each grade was counted and weighed. Marketable fruit was considered the sum of fruit in the US combination and US \#3 grades. There were six harvests in both 2001 and 2002.

Data analysis. Data from both years combined were subjected initially to analysis of variance (ANOVA). It was determined that significant $(P \leq 0.05)$ interactions between years and treatments existed for all height measurements. In addition, treatments interacted with harvests for fruit number and yield in 2002 . Height data then were analyzed separately for each year. Fruit yield and number were analyzed separately for each harvest. Mean separation was performed using a protected least significant difference test $(P \leq 0.05)$.

In each year, gross value of fruit harvested was calculated for each treatment. Weekly average wholesale F.O.B. prices for Western North Carolina were obtained from the marketing division of the North Carolina Dept. of Agriculture and Consumer Services. The yield for each harvest was multiplied by the average price for that week to calculate the value of each harvest. The sum of the values of the six harvests were then subjected to ANOVA.

\section{Results and Discussion}

Plant height. In 2001, after $28 \mathrm{~d}$ in the field, plants from conventionally produced transplants were significantly shorter on day 28 than plants from all float treatments except ethephon-treated seedlings (Table 2). On day 40 , all plants except those from the ethephon and delayed fertilization/brushing treatments were taller than plants grown from conventional transplants (Table 2). In contrast, the plants grown from conventional transplants were the tallest in 2002 on both day 28 and day 40 (Table 2). Plants in the conventional treatment were significantly taller than plants in the high P control, low P control, clipping, ethephon, and delayed fertilization treatments on day 28 and plants in the high P control, low P control, clipping, and ethephon treatments on day 40 . Ethephon-treated transplants resulted in plants significantly shorter than any other treatments on both day 28 and 40. In 2001, the initial

Table 2. Effect of greenhouse cultural practices on field height of tomato plants at 28 and $40 \mathrm{~d}$ after transplanting in 2001 and 2002. Means followed by the same letter are not significantly different (protected LSD) at the 5\% level of probability.

\begin{tabular}{lcccccc}
\hline & \multicolumn{2}{c}{2001} & & \multicolumn{2}{c}{2002} \\
\cline { 2 - 3 } \cline { 6 - 7 } Treatment & Day 28 & Day 40 & & Day 28 & Day 40 \\
\hline Conventional & $41.3 \mathrm{e}$ & $60.3 \mathrm{c}$ & & $58.7 \mathrm{a}$ & $70.4 \mathrm{a}$ \\
High P & $53.5 \mathrm{a}$ & $71.2 \mathrm{a}$ & & $53.0 \mathrm{~b}$ & $64.3 \mathrm{~b}$ \\
Low P & $50.8 \mathrm{ab}$ & $67.7 \mathrm{ab}$ & & $52.7 \mathrm{~b}$ & $63.3 \mathrm{~b}$ \\
Clipping & $47.4 \mathrm{~b}-\mathrm{d}$ & $66.3 \mathrm{~b}$ & & $47.2 \mathrm{c}$ & $56.9 \mathrm{c}$ \\
Ethephon & $43.7 \mathrm{de}$ & $64.5 \mathrm{bc}$ & & $38.6 \mathrm{~d}$ & $49.6 \mathrm{~d}$ \\
Brushing & $45.7 \mathrm{~cd}$ & $65.1 \mathrm{~b}$ & & $55.1 \mathrm{ab}$ & $67.3 \mathrm{ab}$ \\
Delayed fertilization & $49.2 \mathrm{bc}$ & $66.0 \mathrm{~b}$ & & $53.8 \mathrm{~b}$ & $67.2 \mathrm{ab}$ \\
Delayed fertilization/brushing & $45.9 \mathrm{~cd}$ & $63.8 \mathrm{bc}$ & & $54.9 \mathrm{ab}$ & $66.4 \mathrm{ab}$ \\
LSD $_{(0.05)}$ & 3.7 & 4.7 & & 4.9 & 5.1 \\
\hline
\end{tabular}


height of conventional transplants was $3.8 \mathrm{~cm}$ shorter than the shortest float transplants (Table 1), which may have affected the relative field growth of conventionally and float produced transplants. In 2002, however, the initial height of the conventional transplants was similar to float plants that had height restricted by clipping, ethephon, or delayed fertilization plus brushing (Table 1). The increased height responsiveness of conventional transplants in field culture suggests that the high P control, low P control, clipping, ethephon treatments also affect post-transplant growth.

In both years, ethephon had long-lasting effects on plant height. This effect was especially pronounced in 2002, with a height reduction of $13.7 \mathrm{~cm}$ on day 40 compared to the low $\mathrm{P}$ treated transplants. In 2001, ethephon treated transplants produced significantly shorter plants than the low $\mathrm{P}$ treated transplants on day 28 but not on day 40 . This agrees with the findings of Kasperbauer and Hamilton in tobacco (1978).

The height of plants from the low P and high $\mathrm{P}$ pretransplant treatments was similar in all instances (Table 2). Reducing $P$ rate from 3.6 to $1.5 \mathrm{mg} \cdot \mathrm{L}^{-1}$ did not affect post-transplant growth.

Some reduction in post-transplant plant height may be desirable. Workers noted that some of the taller plants, in particular those in the high Pcontrol treatment in 2001, were more difficult to tie. While an analysis of the labor required to tie plants in each treatment was not made, it stands to reason that taller plants are more difficult to tie and could increase labor costs. Also, tall, spindly plants could fall over after transplant and perhaps suffer injury from contact with hot black plastic mulch.

Fruit number and yield. Float-grown transplants, regardless of fertilization or height control treatment, produced numbers and grades of fruit at least as high as conventionally grown transplants in 2001 (Table 3). In addition, total weight of fruit from float-produced transplants was equal to that of conventionally produced transplants (Table 4). Numbers and total weight of US combination grade fruit were higher for the high P control than any other treatment for the first harvest, however, there was no difference in total economic returns (Table 7). There were some small but statistically significant differences in number of US combination and total marketable fruit for harvest six (Table 3 ). Treatments did not affect the number or total weight of US \#3 grade fruit (data not shown). There also was no effect of treatments on the number or total weight of cull fruit (data not shown).

Response to treatments was very different in 2002. As in 2001, treatments did not affect the number or total weight of cull fruit (data not shown). Although season-total fruit number (Table 5) and yield (Table 6) were not affected by treatments, there were significant differences in fruit number and total weight for every harvest. Plants from conventionally grown transplants produced significantly higher fruit number (Table 5) and yield (Table 6) than those from all float treatments in the first harvest in 2002. For harvest two and three, yield of
Table 3. Effect of greenhouse cultural practices on number of tomato fruit for each harvest in the 2001 field experiment. Marketable fruit is the sum of fruit in US combination and US \#3 grades. The total column represents the season total fruit production. Means followed by the same letter are not significantly different (protected LSD) at the 5\% level of probability. Comparisons should only be made within a grade of fruit.

\begin{tabular}{|c|c|c|c|c|c|c|c|}
\hline \multirow[b]{2}{*}{ Treatment } & \multicolumn{6}{|c|}{ Harvest } & \multirow{2}{*}{$\begin{array}{c}\text { Total } \\
\text { no. }\end{array}$} \\
\hline & 1 & 2 & 3 & 4 & 5 & 6 & \\
\hline & \multicolumn{7}{|c|}{ 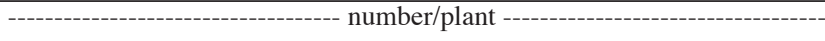 } \\
\hline & \multicolumn{6}{|c|}{ US combination (US \#1 and US \#2) } & \\
\hline Conventional & $0.7 \mathrm{~b}$ & $1.4 \mathrm{a}$ & $4.4 \mathrm{a}$ & $5.3 \mathrm{a}$ & $2.4 \mathrm{a}$ & $1.0 \mathrm{c}$ & $15.2 \mathrm{a}$ \\
\hline High P & $2.4 \mathrm{a}$ & $1.6 \mathrm{a}$ & $4.7 \mathrm{a}$ & $4.4 \mathrm{a}$ & $3.1 \mathrm{a}$ & $1.2 \mathrm{bc}$ & $17.4 \mathrm{a}$ \\
\hline Low P & $1.1 \mathrm{~b}$ & $1.7 \mathrm{a}$ & $2.9 \mathrm{a}$ & $4.1 \mathrm{a}$ & $3.5 \mathrm{a}$ & $1.7 \mathrm{a}-\mathrm{c}$ & $15.0 \mathrm{a}$ \\
\hline Clipping & $1.3 \mathrm{~b}$ & $0.9 \mathrm{a}$ & $3.9 \mathrm{a}$ & $5.0 \mathrm{a}$ & $3.2 \mathrm{a}$ & $2.2 \mathrm{a}$ & $16.6 \mathrm{a}$ \\
\hline Ethephon & $0.9 \mathrm{~b}$ & $1.5 \mathrm{a}$ & $3.2 \mathrm{a}$ & $4.4 \mathrm{a}$ & $2.5 \mathrm{a}$ & $1.3 \mathrm{bc}$ & $13.8 \mathrm{a}$ \\
\hline Brushing & $1.3 \mathrm{~b}$ & $1.6 \mathrm{a}$ & $3.3 \mathrm{a}$ & $6.8 \mathrm{a}$ & $3.0 \mathrm{a}$ & $1.6 \mathrm{a}-\mathrm{c}$ & $17.5 \mathrm{a}$ \\
\hline Delayed fertilization & $1.3 \mathrm{~b}$ & $1.5 \mathrm{a}$ & $2.9 \mathrm{a}$ & $5.4 \mathrm{a}$ & $2.8 \mathrm{a}$ & $2.1 \mathrm{ab}$ & $15.8 \mathrm{a}$ \\
\hline \multicolumn{8}{|l|}{ Delayed fertilization/ } \\
\hline brushing & $0.9 \mathrm{~b}$ & $2.3 \mathrm{a}$ & $4.5 \mathrm{a}$ & $4.9 \mathrm{a}$ & $2.5 \mathrm{a}$ & $1.1 \mathrm{c}$ & $16.3 \mathrm{a}$ \\
\hline \multirow[t]{2}{*}{$\operatorname{LSD}_{(0.05)}$} & 0.8 & NS & NS & NS & NS & 0.9 & NS \\
\hline & \multicolumn{6}{|c|}{ Total marketable fruit (US \#1, US \#2, and US \#3) } & \\
\hline Conventional & $0.9 \mathrm{~b}$ & $1.6 \mathrm{a}$ & $5.1 \mathrm{a}$ & $5.9 \mathrm{a}$ & $3.2 \mathrm{a}$ & $1.1 \mathrm{c}$ & $17.8 \mathrm{a}$ \\
\hline High P & $2.6 \mathrm{a}$ & $1.9 \mathrm{a}$ & $5.5 \mathrm{a}$ & $5.2 \mathrm{a}$ & $4.2 \mathrm{a}$ & $1.3 \mathrm{bc}$ & $20.6 \mathrm{a}$ \\
\hline Low P & $1.4 \mathrm{~b}$ & $1.9 \mathrm{a}$ & $3.8 \mathrm{a}$ & $4.5 \mathrm{a}$ & $4.6 \mathrm{a}$ & $1.9 \mathrm{a}-\mathrm{c}$ & $18.0 \mathrm{a}$ \\
\hline Clipping & $1.5 \mathrm{~b}$ & $1.0 \mathrm{a}$ & $4.8 \mathrm{a}$ & $5.8 \mathrm{a}$ & $4.5 \mathrm{a}$ & $2.7 \mathrm{a}$ & $20.2 \mathrm{a}$ \\
\hline Ethephon & $1.1 \mathrm{~b}$ & $2.2 \mathrm{a}$ & $3.8 \mathrm{a}$ & $4.7 \mathrm{a}$ & $3.1 \mathrm{a}$ & $1.3 \mathrm{bc}$ & $16.2 \mathrm{a}$ \\
\hline Brushing & $1.5 \mathrm{~b}$ & $1.8 \mathrm{a}$ & $3.9 \mathrm{a}$ & $7.6 \mathrm{a}$ & $3.6 \mathrm{a}$ & $1.6 \mathrm{bc}$ & $19.9 \mathrm{a}$ \\
\hline Delayed fertilization & $1.6 \mathrm{~b}$ & $1.7 \mathrm{a}$ & $3.5 \mathrm{a}$ & $5.8 \mathrm{a}$ & $3.2 \mathrm{a}$ & $2.3 \mathrm{ab}$ & $18.0 \mathrm{a}$ \\
\hline \multicolumn{8}{|l|}{ Delayed fertilization/ } \\
\hline brushing & $1.0 \mathrm{~b}$ & $2.5 \mathrm{a}$ & $5.2 \mathrm{a}$ & $5.4 \mathrm{a}$ & $3.2 \mathrm{a}$ & $1.3 \mathrm{bc}$ & $18.6 \mathrm{a}$ \\
\hline $\mathrm{LSD}_{(0.05)}$ & 0.9 & NS & NS & NS & NS & 1.0 & NS \\
\hline
\end{tabular}

NsNonsignificant.

float-produced transplants, with the exception of the clipped transplants for harvest two and ethephon treated transplants for harvests two and three, was similar to that of conventionally grown transplants. Yield of conventionally produced transplants declined to levels below plants from all float treatments (except delayed fertilization plus brushing and delayed fertilization in harvest five and low P control in harvest six) in harvests five and six (Table 6).

The similarity in 2001 of yields and fruit numbers among seedling treatments within harvests indicate an equivalent maturation. In 2002, harvests were delayed for plants from float culture. With the conventional seedling treatment in $2002,92 \%$ of the yield resulted from the first four harvests. In contrast, $83 \%$ of yield from float-produced seedlings treated with delayed fertilization plus brushing and $42 \%$ of yield from float-produced seedlings

Table 4. Effect greenhouse cultural practices on yield of tomato fruit for each harvest in the 2001 field experiment. Marketable fruit is the sum of fruit in US combination and US \#3 grades. The total column represents the season total fruit production. Means followed by the same letter are not significantly different (protected LSD) at the 5\% level of probability. Comparisons should only be made within a grade of fruit.

\begin{tabular}{|c|c|c|c|c|c|c|c|}
\hline \multirow[b]{2}{*}{ Treatment } & \multicolumn{6}{|c|}{ Harvest } & \multirow{2}{*}{$\begin{array}{r}\text { Total } \\
\text { wt }\end{array}$} \\
\hline & 1 & 2 & 3 & 4 & 5 & 6 & \\
\hline & --------- & ----- & ------ & $-\mathrm{t} \cdot \mathrm{ha}^{-1}$ & & & \\
\hline & \multicolumn{6}{|c|}{ US combination (US \#1 and US \#2) } & \\
\hline Conventional & $2.9 \mathrm{~b}$ & $6.2 \mathrm{a}$ & $22.6 \mathrm{a}$ & $24.5 \mathrm{a}$ & $10.1 \mathrm{a}$ & $4.0 \mathrm{a}$ & $70.3 \mathrm{a}$ \\
\hline High P & $10.5 \mathrm{a}$ & $6.5 \mathrm{a}$ & $20.0 \mathrm{a}$ & $19.9 \mathrm{a}$ & $13.2 \mathrm{a}$ & $5.0 \mathrm{a}$ & $75.0 \mathrm{a}$ \\
\hline Low $\mathrm{P}$ & $5.5 \mathrm{~b}$ & $7.2 \mathrm{a}$ & $12.3 \mathrm{a}$ & $17.9 \mathrm{a}$ & $14.7 \mathrm{a}$ & $6.9 \mathrm{a}$ & $64.5 \mathrm{a}$ \\
\hline Clipping & $5.9 \mathrm{~b}$ & $3.8 \mathrm{a}$ & $18.2 \mathrm{a}$ & $23.7 \mathrm{a}$ & $13.6 \mathrm{a}$ & $9.6 \mathrm{a}$ & $74.8 \mathrm{a}$ \\
\hline Ethephon & $3.8 \mathrm{~b}$ & $7.1 \mathrm{a}$ & $13.9 \mathrm{a}$ & $19.9 \mathrm{a}$ & $11.2 \mathrm{a}$ & $5.0 \mathrm{a}$ & $60.8 \mathrm{a}$ \\
\hline Brushing & $5.6 \mathrm{~b}$ & $7.1 \mathrm{a}$ & $14.9 \mathrm{a}$ & $30.3 \mathrm{a}$ & $12.9 \mathrm{a}$ & $7.0 \mathrm{a}$ & $77.8 \mathrm{a}$ \\
\hline Delayed fertilization & $6.4 \mathrm{~b}$ & $7.2 \mathrm{a}$ & $13.4 \mathrm{a}$ & $26.4 \mathrm{a}$ & $11.3 \mathrm{a}$ & $8.7 \mathrm{a}$ & $73.2 \mathrm{a}$ \\
\hline \multicolumn{8}{|l|}{ Delayed fertilization/ } \\
\hline brushing & $4.7 \mathrm{~b}$ & $10.0 \mathrm{a}$ & $19.7 \mathrm{a}$ & $22.3 \mathrm{a}$ & $10.3 \mathrm{a}$ & $4.8 \mathrm{a}$ & $71.7 \mathrm{a}$ \\
\hline \multirow[t]{2}{*}{$\operatorname{LSD}_{(0.05)}$} & 3.9 & NS & NS & NS & NS & NS & NS \\
\hline & \multicolumn{7}{|c|}{ Total marketable fruit (US \#1, US \#2, and US \#3) } \\
\hline Conventional & $3.7 \mathrm{~b}$ & $7.0 \mathrm{a}$ & $25.3 \mathrm{a}$ & $26.8 \mathrm{a}$ & $13.0 \mathrm{a}$ & $4.3 \mathrm{a}$ & $80.1 \mathrm{a}$ \\
\hline High P & $11.4 \mathrm{a}$ & $7.4 \mathrm{a}$ & $22.2 \mathrm{a}$ & $22.1 \mathrm{a}$ & $17.1 \mathrm{a}$ & $5.3 \mathrm{a}$ & $85.5 \mathrm{a}$ \\
\hline Low $\mathrm{P}$ & $6.2 \mathrm{~b}$ & $8.0 \mathrm{a}$ & $15.5 \mathrm{a}$ & $19.0 \mathrm{a}$ & $18.9 \mathrm{a}$ & $7.4 \mathrm{a}$ & $75.0 \mathrm{a}$ \\
\hline Clipping & $6.3 \mathrm{~b}$ & $4.4 \mathrm{a}$ & $21.3 \mathrm{a}$ & $25.9 \mathrm{a}$ & $17.5 \mathrm{a}$ & $10.6 \mathrm{a}$ & $86.1 \mathrm{a}$ \\
\hline Ethephon & $4.7 \mathrm{~b}$ & $9.7 \mathrm{a}$ & $16.2 \mathrm{a}$ & $20.6 \mathrm{a}$ & $12.8 \mathrm{a}$ & $5.2 \mathrm{a}$ & $69.1 \mathrm{a}$ \\
\hline Brushing & $6.5 \mathrm{~b}$ & $8.0 \mathrm{a}$ & $16.6 \mathrm{a}$ & $33.1 \mathrm{a}$ & $14.9 \mathrm{a}$ & $7.1 \mathrm{a}$ & $86.3 \mathrm{a}$ \\
\hline Delayed fertilization & $7.4 \mathrm{ab}$ & $8.2 \mathrm{a}$ & $16.4 \mathrm{a}$ & $27.7 \mathrm{a}$ & $13.0 \mathrm{a}$ & $9.2 \mathrm{a}$ & $81.7 \mathrm{a}$ \\
\hline \multicolumn{8}{|l|}{ Delayed fertilization/ } \\
\hline brushing & $4.9 \mathrm{~b}$ & $10.4 \mathrm{a}$ & $21.9 \mathrm{a}$ & $23.9 \mathrm{a}$ & $12.2 \mathrm{a}$ & $5.3 \mathrm{a}$ & $78.4 \mathrm{a}$ \\
\hline $\operatorname{LSD}_{(0.05)}$ & 4.2 & NS & NS & NS & NS & NS & NS \\
\hline
\end{tabular}

${ }^{\mathrm{N}}$ Nonsignificant. 
treated with ethephon was obtained in the first four harvests. With fresh market tomatoes, prices are usually greater early in the season (Davis and Estes, 1993). Factors that delay harvest potentially reduce economic returns. The ideal situation is to have large yields of high-quality fruit in the first few harvests.

Plants from float-grown seedlings produced with high $\mathrm{P}$ fertility had highest yields for harvest one in 2001 (Table 4). Yields from the high $\mathrm{P}$ and low $\mathrm{P}$ seedlings were not different in harvests two through six in 2001 (Table 4) and all 2002 harvests (Table 6). In addition, the total yield was not different among transplants produced in float culture with low and high P fertility and produced conventionally. Conventionally produced transplants received far more $\mathrm{P}$ during pretransplant growth than the float-grown transplants. The lack of yield response to $\mathrm{P}$ fertilization of transplants indicates that low $\mathrm{P}$ fertilization levels of tomato in the float system was not detrimental to total field fruit yield or economic returns under the conditions of this study. This is in contrast to the findings of Liptay et al. (1992) and Melton and Dufault (1991), which were based on conventional irrigation and fertilization. However, the lack of damage to field performance by low Pin the float system observed here is consistent with observations with float-grown tobacco seedlings (Rideout and Gooden, 1998, 2000). It is possible that, by elimination of nutrient leaching from the flats, the float system has a nutrient use efficiency that is greater than that of conventional systems, thus lowering the required rate of pretransplant $\mathrm{P}$ for subsequent unimpaired field growth.

There were no significant differences in fruit number and yield between transplants that received the delayed fertilization and delayed fertilization plus brushing treatments in 2001 (Tables 3 and 4) or 2002 (Tables 5 and 6). Addition of brushing to the delayed fertilization practice had no effect in the field, but it did improve height control during transplant production (Rideout and Overstreet, 2003). Both treatments slightly delayed maturity with respect to the conventionally grown transplants.

The combination of brushing with low $\mathrm{P}$ fertilizer is also effective for control of transplant height (Rideout and Overstreet, 2003). Transplants treated by brushing or low $\mathrm{P}$ produced similar fruit numbers and yields similar on all harvests in 2001 (Tables 3 and 4) and 2002 (Tables 5 and 6). This suggests that even though float production resulted in maturity delays in 2002, the delays were not worsened by brushing, and additional height control was obtained. Combining delayed fertilization with brushing increased harvest two yields in 2002 as compared to brushing alone (Table 6).

Clipping has been reported to provide height control similar to brushing in the float system (Rideout and Overstreet, 2003). However, in 2002, clipping delayed maturity more than brushing, as evidenced by lower yield in harvest one. Given the difficulty in properly clipping plants without damage to the apical meristem, and the availability of other effective height control practices, clip-

Table 5. Effect of greenhouse cultural practices on number of tomato fruit for each harvest in the 2002 field experiment. Marketable fruit is the sum of fruit in US combination and US \#3 grades. The total column represents the season total fruit production. Means followed by the same letter are not significantly different (protected LSD) at the $5 \%$ level of probability. Comparisons should only be made within a grade of fruit.

\begin{tabular}{|c|c|c|c|c|c|c|c|}
\hline \multirow[b]{2}{*}{ Treatment } & \multicolumn{6}{|c|}{ Harvest } & \multirow{2}{*}{$\begin{array}{c}\text { Total } \\
\text { Number }\end{array}$} \\
\hline & 1 & 2 & 3 & 4 & 5 & 6 & \\
\hline & \multicolumn{6}{|c|}{ US Combination Fruit (US\#1 and US \#2) } & \\
\hline Conventional & $4.1 \mathrm{a}$ & $3.4 \mathrm{ab}$ & $6.9 \mathrm{ab}$ & $5.4 \mathrm{bc}$ & $1.3 \mathrm{~b}$ & $0.3 \mathrm{c}$ & $21.3 \mathrm{a}$ \\
\hline High P & $0.7 \mathrm{bc}$ & $2.7 \mathrm{ab}$ & $5.5 \mathrm{ab}$ & $4.7 \mathrm{c}$ & $5.6 \mathrm{a}$ & $1.9 \mathrm{~b}$ & $21.1 \mathrm{a}$ \\
\hline Low $\mathrm{P}$ & $0.4 \mathrm{bc}$ & $2.6 \mathrm{bc}$ & $4.3 \mathrm{~b}$ & $6.6 \mathrm{~b}$ & $6.5 \mathrm{a}$ & $1.3 \mathrm{bc}$ & $21.6 \mathrm{a}$ \\
\hline Clipping & $0.2 \mathrm{c}$ & $1.5 \mathrm{~cd}$ & $4.7 \mathrm{ab}$ & $8.8 \mathrm{a}$ & $6.5 \mathrm{a}$ & $1.6 \mathrm{~b}$ & $23.3 \mathrm{a}$ \\
\hline Ethephon & $0.4 \mathrm{bc}$ & $1.2 \mathrm{~d}$ & $1.2 \mathrm{c}$ & $4.6 \mathrm{c}$ & $7.3 \mathrm{a}$ & $4.3 \mathrm{a}$ & $19.0 \mathrm{a}$ \\
\hline Brushing & $1.0 \mathrm{~b}$ & $2.4 \mathrm{~b}-\mathrm{d}$ & $6.1 \mathrm{ab}$ & $6.3 \mathrm{bc}$ & $5.6 \mathrm{a}$ & $1.5 \mathrm{~b}$ & $22.8 \mathrm{a}$ \\
\hline Delayed fertilization & $0.7 \mathrm{bc}$ & $3.3 \mathrm{ab}$ & $5.6 \mathrm{ab}$ & $6.0 \mathrm{bc}$ & $2.5 \mathrm{~b}$ & $1.3 \mathrm{bc}$ & $19.5 \mathrm{a}$ \\
\hline Delayed fertilization/brushing & $0.9 \mathrm{~b}$ & $3.9 \mathrm{a}$ & $7.3 \mathrm{a}$ & $4.9 \mathrm{bc}$ & $2.2 \mathrm{~b}$ & $1.4 \mathrm{~b}$ & $20.5 \mathrm{a}$ \\
\hline $\mathrm{LSD}_{(0.05)}$ & 0.7 & 1.2 & 3.0 & 1.9 & 2.8 & 1.0 & NS \\
\hline \multicolumn{8}{|c|}{ Total Marketable Fruit (US\#1, US \#2, and US\#3) } \\
\hline Conventional & $4.1 \mathrm{a}$ & $3.8 \mathrm{a}$ & $7.9 \mathrm{a}$ & $6.0 \mathrm{~b}$ & $1.5 \mathrm{~b}$ & $0.4 \mathrm{c}$ & $23.6 \mathrm{a}$ \\
\hline High P & $0.7 \mathrm{bc}$ & $2.8 \mathrm{ab}$ & $5.8 \mathrm{ab}$ & $5.1 \mathrm{~b}$ & $6.2 \mathrm{a}$ & $2.4 \mathrm{~b}$ & $23.0 \mathrm{a}$ \\
\hline Low P & $0.4 \mathrm{bc}$ & $2.7 \mathrm{a}-\mathrm{c}$ & $4.4 \mathrm{~b}$ & $7.0 \mathrm{~b}$ & $7.3 \mathrm{a}$ & $1.7 \mathrm{~b}$ & $23.5 \mathrm{a}$ \\
\hline Clipping & $0.2 \mathrm{c}$ & $1.5 \mathrm{~cd}$ & $4.9 \mathrm{ab}$ & $9.4 \mathrm{a}$ & $7.0 \mathrm{a}$ & $2.1 \mathrm{~b}$ & $25.0 \mathrm{a}$ \\
\hline Ethephon & $0.4 \mathrm{bc}$ & $1.2 \mathrm{~d}$ & $1.3 \mathrm{c}$ & $5.0 \mathrm{~b}$ & $7.9 \mathrm{a}$ & $4.9 \mathrm{a}$ & $20.7 \mathrm{a}$ \\
\hline Brushing & $1.0 \mathrm{~b}$ & $2.5 \mathrm{~b}-\mathrm{d}$ & $6.2 \mathrm{ab}$ & $7.0 \mathrm{~b}$ & $6.2 \mathrm{a}$ & $2.2 \mathrm{~b}$ & $25.0 \mathrm{a}$ \\
\hline Delayed fertilization & $0.7 \mathrm{bc}$ & $3.4 \mathrm{ab}$ & $6.1 \mathrm{ab}$ & $6.4 \mathrm{~b}$ & $3.0 \mathrm{~b}$ & $1.7 \mathrm{~b}$ & $21.2 \mathrm{a}$ \\
\hline Delayed fertilization/brushing & $0.9 \mathrm{~b}$ & $3.9 \mathrm{a}$ & $7.4 \mathrm{ab}$ & $5.2 \mathrm{~b}$ & $2.3 \mathrm{~b}$ & $2.0 \mathrm{~b}$ & $21.7 \mathrm{a}$ \\
\hline $\operatorname{LSD}_{(0.05)}$ & 0.7 & 1.3 & 3.0 & 2.0 & 3.1 & 1.1 & NS \\
\hline
\end{tabular}

Ns Nonsignificant.

ping tomatoes in the float system should not be a recommended practice.

Although not significantly different from other treatments, total yields for transplants treated with ethephon were lowest in 2001 (Table 4) and 2002 (Table 6). Fruit number and yield in each of the first three harvests was significantly lower than for conventionally grown transplants in 2002 (Tables 5 and 6). Maturity was severely delayed by ethephon treatment in 2002 , with only $18 \%$ of the fruit harvested in the first three harvests, compared to $69 \%$ for conventionally grown. Ethephon application in conventional transplant production did not harm or even improved field performance of tomato transplants (Campbell, 1976; Liptay et al., 1981; Pisarczyk and Splittstoesser, 1979). Apparently, float-grown transplants respond differently to ethephon application than conventionally grown transplants.

Transplant treatment in the greenhouse did not affect gross monetary returns in either year (Table 7). Float grown transplants produced gross monetary return equal to conventionally

Table 6. Effect of greenhouse cultural practices on yield of tomato fruit for each harvest in the 2002 field experiment. Marketable fruit is the sum of fruit in US combination and US \#3 grades. The total column represents the season total fruit production. Means followed by the same letter are not significantly different (protected LSD) at the 5\% level of probability. Comparisons should only be made within a grade of fruit.

\begin{tabular}{|c|c|c|c|c|c|c|c|}
\hline \multirow[b]{2}{*}{ Treatment } & \multicolumn{6}{|c|}{ Harvest } & \multirow{2}{*}{$\begin{array}{c}\text { Total } \\
\text { wt }\end{array}$} \\
\hline & 1 & 2 & 3 & 4 & 5 & 6 & \\
\hline & \multicolumn{7}{|c|}{ 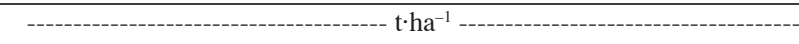 } \\
\hline \multicolumn{8}{|c|}{ US Combination Fruit (US\#1 and US \#2) } \\
\hline Conventional & $15.4 \mathrm{a}$ & $13.6 \mathrm{ab}$ & $27.1 \mathrm{ab}$ & $18.6 \mathrm{bc}$ & $4.9 \mathrm{c}$ & $1.2 \mathrm{c}$ & $80.6 \mathrm{a}$ \\
\hline High P & $3.4 \mathrm{bc}$ & $12.3 \mathrm{~b}$ & $23.3 \mathrm{ab}$ & $17.1 \mathrm{c}$ & $19.2 \mathrm{a}$ & $6.1 \mathrm{~b}$ & $81.3 \mathrm{a}$ \\
\hline Low P & $2.2 \mathrm{bc}$ & $12.6 \mathrm{~b}$ & $17.3 \mathrm{bc}$ & $23.2 \mathrm{a}-\mathrm{c}$ & $22.1 \mathrm{a}$ & $3.9 \mathrm{bc}$ & $81.3 \mathrm{a}$ \\
\hline Clipping & $0.6 \mathrm{c}$ & $6.8 \mathrm{c}$ & $19.8 \mathrm{ab}$ & $29.4 \mathrm{a}$ & $22.6 \mathrm{a}$ & $6.1 \mathrm{~b}$ & $85.2 \mathrm{a}$ \\
\hline Ethephon & $1.5 \mathrm{bc}$ & $6.2 \mathrm{c}$ & $5.9 \mathrm{c}$ & $17.9 \mathrm{bc}$ & $27.6 \mathrm{a}$ & $14.4 \mathrm{a}$ & $73.4 \mathrm{a}$ \\
\hline Brushing & $4.3 \mathrm{~b}$ & $10.8 \mathrm{bc}$ & $26.7 \mathrm{ab}$ & $24.1 \mathrm{ab}$ & $17.8 \mathrm{ab}$ & $5.0 \mathrm{~b}$ & $88.7 \mathrm{a}$ \\
\hline Delayed fertilization & $3.5 \mathrm{bc}$ & $15.1 \mathrm{ab}$ & $25.0 \mathrm{ab}$ & $24.1 \mathrm{ab}$ & $9.1 \mathrm{bc}$ & $4.4 \mathrm{bc}$ & $81.2 \mathrm{a}$ \\
\hline Delayed fertilization/brushing & $3.9 \mathrm{~b}$ & $17.7 \mathrm{a}$ & $31.0 \mathrm{a}$ & $18.8 \mathrm{bc}$ & $8.4 \mathrm{bc}$ & $5.2 \mathrm{~b}$ & $85.0 \mathrm{a}$ \\
\hline $\operatorname{LSD}_{(0.05)}$ & 3.3 & 4.8 & 12.4 & 6.4 & 9.9 & 3.8 & NS \\
\hline \multicolumn{8}{|c|}{ Total Marketable Fruit (US\#1, US \#2, and US\#3) } \\
\hline Conventional & $15.4 \mathrm{a}$ & $14.4 \mathrm{ab}$ & $30.5 \mathrm{ab}$ & 20.2 bc & $5.8 \mathrm{c}$ & $1.3 \mathrm{c}$ & $87.4 \mathrm{a}$ \\
\hline High P & $3.4 \mathrm{bc}$ & $12.7 \mathrm{~b}$ & $24.6 \mathrm{ab}$ & $17.9 \mathrm{c}$ & $20.6 \mathrm{ab}$ & $7.3 \mathrm{~b}$ & $86.4 \mathrm{a}$ \\
\hline Low P & $2.2 \mathrm{bc}$ & $13.0 \mathrm{~b}$ & $17.9 \mathrm{bc}$ & $24.3 \mathrm{a}-\mathrm{c}$ & $23.8 \mathrm{a}$ & $4.9 \mathrm{bc}$ & $86.1 \mathrm{a}$ \\
\hline Clipping & $0.6 \mathrm{c}$ & $6.9 \mathrm{~cd}$ & $20.6 \mathrm{ab}$ & $30.6 \mathrm{a}$ & $24.1 \mathrm{a}$ & $7.8 \mathrm{~b}$ & $90.4 \mathrm{a}$ \\
\hline Ethephon & $1.5 \mathrm{bc}$ & $6.2 \mathrm{~d}$ & $6.5 \mathrm{c}$ & $19.1 \mathrm{bc}$ & $29.3 \mathrm{a}$ & $15.8 \mathrm{a}$ & $78.3 \mathrm{a}$ \\
\hline Brushing & $4.3 \mathrm{~b}$ & $11.1 \mathrm{bc}$ & $27.4 \mathrm{ab}$ & $25.8 \mathrm{ab}$ & $19.6 \mathrm{ab}$ & $6.9 \mathrm{~b}$ & $94.9 \mathrm{a}$ \\
\hline Delayed fertilization & $3.5 \mathrm{bc}$ & $15.5 \mathrm{ab}$ & $26.2 \mathrm{ab}$ & $25.3 \mathrm{ab}$ & $10.5 \mathrm{bc}$ & $5.5 \mathrm{~b}$ & $86.5 \mathrm{a}$ \\
\hline Delayed fertilization/brushing & $3.9 \mathrm{~b}$ & $18.2 \mathrm{a}$ & $31.4 \mathrm{a}$ & $19.6 \mathrm{bc}$ & $8.6 \mathrm{c}$ & $6.8 \mathrm{~b}$ & $88.5 \mathrm{a}$ \\
\hline $\mathrm{LSD}_{(0.05)}$ & 3.3 & 4.7 & 12.7 & 6.7 & 10.4 & 3.9 & NS \\
\hline
\end{tabular}

NsNonsignificant. 
Table 7. Effect of greenhouse cultural practices on gross value of tomato fruit in 2001 and 2002.

\begin{tabular}{|c|c|c|}
\hline \multirow[b]{2}{*}{ Treatment } & \multicolumn{2}{|c|}{ Gross value } \\
\hline & 2001 & 2002 \\
\hline & \multicolumn{2}{|c|}{------- \$/ha ------- } \\
\hline Conventional & 41,758 & 37,065 \\
\hline High $\mathrm{P}$ control & 45,909 & 36,342 \\
\hline Low P control & 42,147 & 35,791 \\
\hline Clipping & 48,060 & 37,383 \\
\hline Ethephon & 36,996 & 32,700 \\
\hline Brushing & 46,974 & 39,685 \\
\hline Delayed fertilization & 44,600 & 36,379 \\
\hline Delayed fertilization/brushing & 41,074 & 37,584 \\
\hline $\operatorname{LSD}_{(0.05)}$ & NS & NS \\
\hline
\end{tabular}

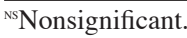

grown transplants. Although not statistically significant, ethephon-treated float transplants had the lowest returns in both years. During the two years of this study, early fruit prices were only slightly higher than later prices, and prices increased late in the season. This late season increase offset the loss of early season yield for the ethephon treatments (data not shown). If previously reported price patterns occur (earlier fruit sells for much higher prices) (Davis and Estes, 1993), ethephon application has the potential to reduce economic returns, and therefore can not be recommended for tomato seedlings grown in the float system.

There were differences in the results the two years of the study, with much more effect of treatments observed in 2002. There was a delay in beginning the experiment in 2001, and the transplanting date was later than normal for western North Carolina. It is possible that the environmental conditions imposed by late transplanting may have masked field response to greenhouse treatments.

\section{Conclusions}

Previous results (Rideout and Overstreet, 2003) show that use of height-limiting cultural practices such as low $\mathrm{P}$ fertilizer, delayed fertilization, and brushing improves the quality of tomato transplants grown in the float system. This study shows that use of delayed fertilization or delayed fertilization with brushing along with low $\mathrm{P}$ fertilizer results in little damage to overall field performance. There was a slight maturity delay with these treatments in one year of the study, but the delay was minimal and overall yields were identical to plants grown from conventionally produced transplants.

Use of clipping and ethephon to control the height of tomato transplants in the float system is not recommended. Severe harvest delays can occur with ethephon treatment. With clipping it is too easy to damage the apical meristem of the plant. Not having these practices available is of little consequence, since low P fertilizer, brushing, and delayed fertilization not only work as well in the greenhouse (Rideout and Overstreet, 2003), but are also easier to manage and have less potential to damage field performance. With these practices, the float system can be used in place of the more labor-intensive conventional overhead irrigation system with little damage to field performance.

\section{Literature Cited}

Bar-Tal, A., B. Bar-Yosef, and U. Kafkafi. 1990. Pepper transplant response to root volume and nutrition in the nursery. Agron. J. 82:989-995.

Campbell, G.M. 1976. Effect of ethephon and SADH on quality of clipped and nonclipped tomato transplants. J. Amer. Soc. Hort. Sci. 101:648-651.

Davis, J.M. and E.A. Estes. 1993. Spacing and pruning affect growth, yield, and economic returns of staked fresh-market tomatoes. J. Amer. Soc. Hort. Sci. 118:719-725.

Dufault, R.J. 1998. Vegetable transplant nutrition. HortTechnology 8:515-523.

Dufault, R.J. and J.R. Schultheis. 1994. Bell pepper seedling growth and yield following pre-transplant nutritional conditioning. HortScience 29: 999-1007.

Garner, L.C. and T. Bjorkman. 1999. Mechanical conditioning of tomato seedlings improves transplant quality without deleterious effects on field performance. HortScience 34:848-851.

Hartz, T.K., C. Giannini, E.M. Miyao, and J.G. Valencia. 2002. Divergent transplant production practices produce comparable growth, yield, and quality of processing tomatoes.

Johjima, T., J.G. Latimer, and H. Wakita. 1992. Brushing influences transplant growth and subsequent yield of four cultivars of tomato and their hybird lines. J. Amer. Soc. Hort. Sci. 117:384-388.
Kasperbauer, M.J. and J.L. Hamilton. 1978. Ethyleneregulation of tobacco seedling size, floral induction, and subsequent growth and development. Agron. J. 70:363-366.

Konsler, T.R. and R.G. Gardner. 1990. Commercial production of staked tomatoes in North Carolina. N.C. Agr. Ext. Serv. Pub. AG-405.

Liptay, A., C.A. Jaworski, and S.C. Phatak. 1981. Effect of tomato transplant stem diameter and ethephon treatment on tomato yield, fruit size, and number. Can. J. Plant Sci. 61:413-415.

Liptay, A., S. Nicholls, and P. Sikkema. 1992. Optimal mineral nutrition of tomato transplants in the greenhouse for maximum performance in the field. Acta Hort. 319:489-492.

Melton, R.R. and R.J.Dufault. 1991. Tomato seedling growth, earliness, yield, and quality following pretransplant nutritional conditioning and low temperatures. J. Amer. Soc. Hort. Sci. 116: 421-425.

Nicola, S. and L. Basoccu. 1994. Pre-transplant nutritional conditioning affects pepper seedling growth and yield. Acta Hort. 361:519-526.

Pisarczyk, J.M. and W.E. Splittstoesser. 1979. Response of tomato to pre-transplanting applications of chlormequat, daminozide, and ethephon. HortScience 14:263-264.

Rideout, J.W., D.T. Gooden, G.D. Christenbury, B.A. Fortnum, D.G. Manley, and R.W. Sutton. 1994. Tobacco transplant production in greenhouses. Clemson Univ. Coop. Ext. Serv. Cir. 682.

Rideout,J.W. and D.T. Gooden. 1998. Phosphorus nutrition of tobacco seedlings grown in greenhouse float culture. J. Plant Nutr. 21:307-319.

Rideout, J.W. and D.T. Gooden. 2000. Effects of starter fertilizer, granular phosphorus fertilizer, time of fertilization, and seedling phosphorus concentration on flue-cured tobacco growth and nutrition. Tob. Sci. 44:19-26.

Rideout, J.W. and L.F. Overstreet. 2003. Phosphorus rate in combination with cultural practices reduces excessive growth of tomato seedlings in the float system. HortScience 38:524-528.

Vavrina, C.S., G.J.Hochmuth, J.A. Cornell, and S.M. Olson. 1998. Nitrogen fertilization of Floridagrown tomato transplants: seasonal variation in greenhouse and field performance. HortScience $33: 251-254$

Wyatt, J.E. 1998. Tomato transplant production using the float system and cupric hydroxide. HortTechnology 8:366-369.

U.S. Dept. of Agriculture. 1997. United States standards for grades of fresh tomatoes. U.S. Dept. Agr., Agr. Mktg. Serv., Fruit and Vegetable Div. 